\title{
Implied Age of Kolhan Basin: Tectonic Implication
}

\author{
Kasturi Bhattacharyya* \\ IIT Kharagpur, India \\ Submission: February 23, 2017; Published: March 24, 2017 \\ *Corresponding author: Kasturi Bhattacharyya, IIT Kharagpur, India, Email: bhattacharyya.kasturi@gmail.com
}

\section{Mini Review}

The age of the Kolhan Basin was mysterious. Careful literature review and logical constraints from available data in literature can constrain the age. The maximum age of Kolhan Basin (closing) is 1531Ma from whole rock $\mathrm{Rb} / \mathrm{Sr}$ age of Kolhan shale [1] and opening of basin corresponds to Dalma plume (1600 Ma)-[2,3]. Hence the duration or life of Kolhan Basin corresponds to 30Ma. The Dalma plume magmatism was possibly part of a $1600 \mathrm{Ma}$ global tectono-thermal event. This is synchronous to the existence of the Columbia supercontinent. The implied age directly gives the tectonic implication of the basin.

The Proterozoic sedimentary sequence consisting successively younger Dhanjori, Chaibasa, Dhalbhum, Dalma and Chandil Formation of the Singhbhum crustal province, India records sedimentation in a quick changing tectonic scenario. The cooling down of the vast volume of Archaean Singhbhum Granite induced an isostatic readjustment. The associated tensional tectonic regime and deep seated fractures controlled the formation of the Proterozoic Kolhan basin.

The entire Late Proterozoic volcano-sedimentary package displays post-depositional compressional deformation and greenschist to amphibolite facies metamorphism which has been dated at ca. $1600 \mathrm{Ma}$, forming the North Singhbhum fold belt. The volcano-sedimentary package lying south to the Dalmavolcanic belt was pushed south towards the Singhbhum granite batholith complex as a result of uplift related to the Dalma plume. The Singhbhum granite batholith acted as a rigid body. This gave rise to compressional stress regime that induced shearing/ thrusting at ca. $1600 \mathrm{Ma}$ along the Singhbhum Shear Zone. The Dalma plume magmatism was possibly part of a $1600 \mathrm{Ma}$ global tectono-thermal event.

A simple model for the development and evolution of the Kolhan Basin is proposed. The first event consists of a rapid stretching of the continental lithosphere, which produced thinning and passive upwelling of hot asthenosphere. This stage is connected with block faulting and subsidence. The lithosphere then thickens by heat conduction to the surface and further slow subsidence occurs which is not connected with faulting. The slow subsidence and the heat flow depend only on the amount of stretching, which can be estimated from these quantities and from the change in the thickness of the continental crust caused by the extension. The maximum age of Kolhan Basin (closing) is 1531Ma from whole rock $\mathrm{Rb} / \mathrm{Sr}$ age of Kolhan shale [1] and opening of basin corresponds to Dalma plume (1600Ma $[2,3]$. Hence the duration or life of Kolhan Basin corresponds to 30Ma. The Dalma plume magmatism was possibly part of a $1600 \mathrm{Ma}$ global tectono-thermal event. This is synchronous to the existence of the Columbia supercontinent (supported by Figure 1 data). There was no glaciation during the existence of Columbia supported by Figure 2 . This indicates moderate weathering rate during which the Kolhan Basin formed. This logical conclusion is supported by the predominance of quartz arenite in the sandstone of the basin [4]. This supports the findings of Bhattacharyya et al. [4] that the Kolhan Basin is product of the rift basin that after gaining tectonic quiescence became an intracratonic region (passive margin). The paucity of feldspars in the thin sections supports the above findings [5].

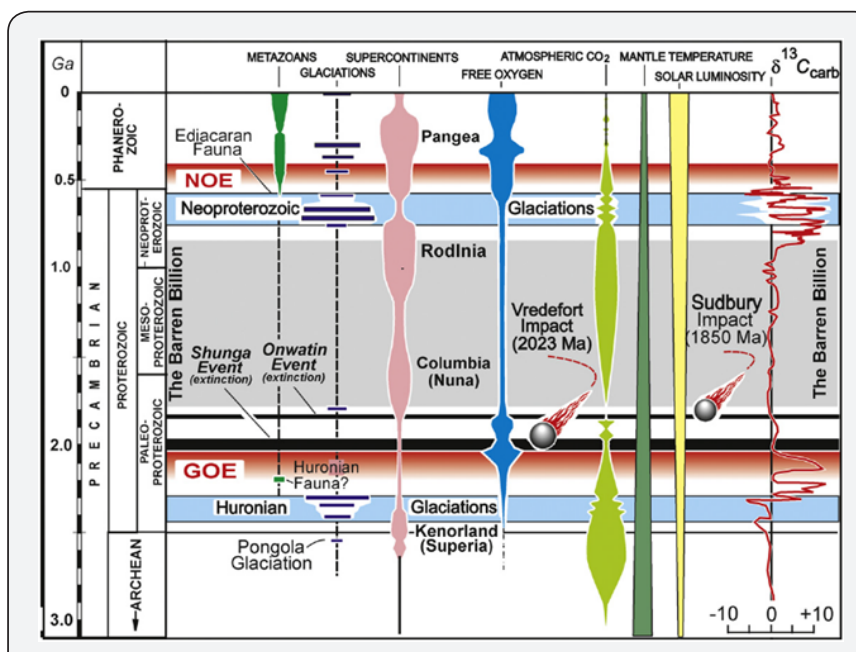

Figure 1: The diagram after Young et al. [5] shows the existence of Columbia supercontinent at $1600 \mathrm{Ma}$. 


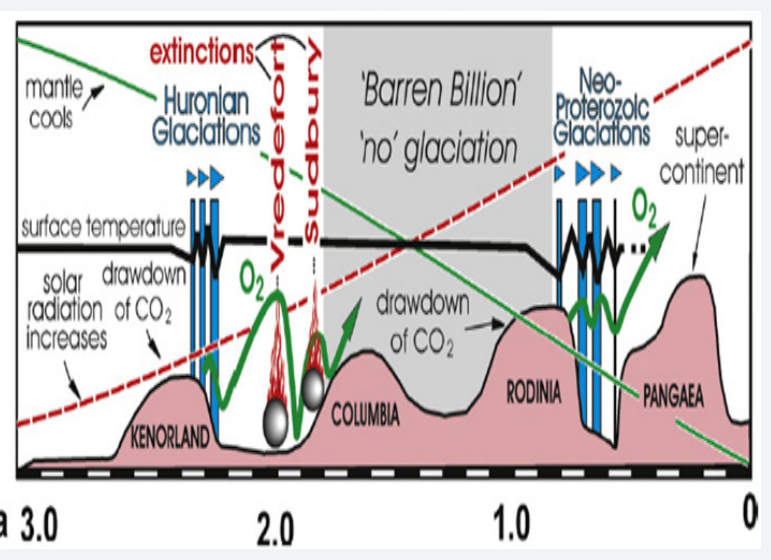

Figure 2: Climatic perturbations in the Proterozoic (diagram after Young et al. [5]).

\section{References}

1. Bandopadhyay PC, Sengupta S (2004) Paleoproterozoic supracrustal Kolhan Group in Singhbhum craton, India and the Indo-African Supercontinent. Gondwana Research 7(4): pp.1228-1235.

2. Kent $R$ (1991) Lithospheric uplift in eastern Gondwana: evidence for a long-lived mantle plume system? Geology 19(1): 19-23.

3. Roy A, Sarkar A, Jeyakumar S, Aggrawal SK, Ebihara M (2002) MidProterozoic Plume-related thermal event in Eastern Indian Craton: evidence from trace elements, REE geochemistry and Sr-Nd isotope systematics of basic-ultrabasic intrusives from Dalma Volcanic Belt. Gondwana Research 5(1): 133-146.

4. Bhattacharyya K, Das S (2015) Sandstone Petrology and Geochemistry of the Kolhan Basin, Eastern India: Implications for Basin Tectonics. Journal of Geology and Geoscience 4(2): pp. 1-6.

5. Grant MY (2013) Precambrian Supercontinent, glaciations, atmospheric oxygenation, metazoan evolution and an impact that may have changed the second half of Earth history. Geoscience Frontiers 4(3): 247-261.

\section{Your next submission with Juniper Publishers will reach you the below assets}

- Quality Editorial service

- Swift Peer Review

- Reprints availability

- E-prints Service

- Manuscript Podcast for convenient understanding

- Global attainment for your research

- Manuscript accessibility in different formats

( Pdf, E-pub, Full Text, Audio)

- Unceasing customer service

Track the below URL for one-step submission https://juniperpublishers.com/online-submission.php 